\title{
Multicultural Education Management
}

\author{
(A Case Study at SMP/MTs in Bali Province)
}

\author{
I Gusti Ketut Arya Sunu* \\ Educational Administration Department \\ Universitas Pendidikan Ganesha \\ Singaraja, Indonesia \\ *arya.sunu@undiksha.ac.id
}

\begin{abstract}
This research aimed at 1) revealing the background of the multicultural education management (MEM) program and the process of developing multicultural education, 2) determining the MEM program's success at SMP/MTs in Bali Province, and 3) identifying the challenges of MEM program implementation. The researcher did the study at SMP/MTs in Bali Province by using a mixed-method approach. The researcher used a qualitative approach to identify the background and the process of MEM program development. Simultaneously, a quantitative approach with the Content Input Process Product (CIPP) evaluation model was done to determine the MEM program's success. The results of the study reveal that the MEM program's background consists of historical, philosophical, juridical, sociological, geographical, and futuristic backgrounds, and the development process of the MEM program was created through three different forms: the idea, concept, value, and norm; multicultural activity; and students' real act. The evaluation using the CIPP evaluation model determines that the MEM is highly successful. While the challenges faced on the implementation of MEM program, namely: lack of contribution from the society, socio-economic problems, lack of stakeholders understanding on the mission of MEM program, lack of infrastructure, lack of collaboration and participation, and low non-academic achievement.
\end{abstract}

Keywords-CIPP evaluation model, success, multicultural education management

\section{INTRODUCTION}

A multicultural or diverse society is a distinctive feature, and it is an inseparable part of the Indonesian people and nation's life. From the social perspective, education is demanded to produce educated people who have an important role in social change. Education is a determinant factor in encouraging the acceleration of community mobility, which leads to the formation of new social formations [1]. This new social formation consists of an educated middle class, an important element in strengthening social cohesion [2].

In a society with a diverse socio-cultural background, a multicultural education becomes a vital thing. Multicultural education is an educational reform that aims to change schools from elementary to tertiary levels in order to provide students of various races, ethnicities, cultures, languages, social classes, and religions the same educational opportunities [3]. The implementation of a MEM development program at junior high schools (SMP/MTs) in Bali has been going on since the 2007/2008 school year. However, the evaluation of the cultural education implementation has never been done.

Education evaluation is vital to determine student progress, reorganize education systems, improve liability for outcomes, measure program interventions success, and measure the education program's accountability [4-9]. A critical and systematic assessment is critical to be conducted to see the significance of the multicultural education program for the ultimate goal and the school, namely the realization of students with multicultural education. Program evaluation is needed to carefully determine the policy's implementation level by knowing each component's success. Some researchers have conducted studies on the evaluation of multicultural education. However, those studies mostly evaluated multicultural education partially. The former studies only evaluated multicultural education from the teaching design program [10], curriculum design [11], culture, learning styles, and creativity [12], learning groups [13], and living, learning, school activities, and community life [14] point of views. No study was conducted to evaluate multicultural education holistically from its context, inputs, processes, and outcomes.

An evaluation model that measures the context, input, process, and product, known as the CIPP evaluation model, has been proven to be an effective way to conduct the educational evaluation by some researchers [15-18]. Thus, the objectives of this research can be conveyed, among others: (1) to identify the background of the multicultural education management (MEM) program and the process of developing multicultural education, 2) to determine the MEM program's success at SMP/MTs in Bali Province, and 3) to identify the challenges of MEM program implementation.

\section{METHODS}

This study took place in four junior high schools, namely SMP Lab Undiksha Singaraja, SMP Negeri I Singaraja, MTs Negeri Patas, and MTs Tegalinggah. It applied a mixed-method approach in the form of a sequential transformative strategy [19]. The qualitative approach aimed to answer problems about 
multicultural education development and the process of developing multicultural education [2]. The quantitative approach was conducted through the CIPP evaluation model. The CIPP Stufflebeam model consists of four variables. Those variables are context, input, process, and outcome (product) [20]. The data obtained from the MEM program evaluation were used to look for challenges to implementing the program. Findings of the various obstacles faced in the program help the researcher to seek alternative solutions. The solution offered by the researcher is based on a qualitative analysis that is linked to existing theories.

\section{RESULTS AND DISCUSSION}

\section{A. The Background of MEM Program}

The results showed that the general description of SMP/MTs, which were used as the object of research in the MEM program, was very easy to access information and find the need for educational materials because they were located in the community area, which was still strong in their culture. This is very positive for developing school programs concerning democracy, cooperation, and togetherness to make the MEM program successful.

The background of MEM consists of:

- historical background in the form of a history of the development of school-based multicultural education,

- the philosophical background that is related to the essence of education that balances intellectual intelligence and emotional intelligence,

- juridical background by the realization of the ministerial regulation on graduate competency standards and content standards,

- background sociology, which is the people's profession that requires a lot of social interaction dealing with a pluralistic society,

- a geographical background by the presence of various ethnicities in one area and a futuristic background, which is multicultural culture is a capital for national independence amid diversity and differences that occur in the world.

The process of developing multicultural education occurs through cultural forms, namely the form of ideas, values, norms, art, activities for implementing multicultural culture, and real student work.

The findings of the former studies support the result of this study. The previous studies conducted to study multicultural education also found that multicultural education implementation includes the socio-cultural situation of the society that consists of people with various socio-cultural backgrounds [21-23].

\section{B. The Success of MEM Program}

The evaluation of the MEM program using the CIPP model program evaluation obtained the following results.

a. In the background variable (context), which consists of seven indicators, five indicators have positive values: geographical background, government policy, school vision, school mission, and school objectives. Two indicators with negative values are community participation and the community's socio-economic status so that the background variable is positive.

b. The input variable consisting of 10 indicators obtained eight positive value indicators, namely: program vision, program objectives, mapping of competency standard/ basic competency of the programs, MEM program syllabus, program implementation plans, evaluation system, teachers, and students; The two negative indicators are the mission of the program and infrastructure, so the input variable is positive.

c. The process variable consists of seven indicators. There are five positive indicators, namely: decision-making process, institutional management process, learning process, financial management process, and evaluation process; Two indicators that are negative or classified as low are indicators of the program management process and the process of cooperation and participation so that the process variable has a positive value.

d. The outcome variable (product) consists of four indicators. Two indicators have positive values, namely, students' real work and the quality of multicultural education. The two negative indicators are community response and non-academic achievement, then the outcome variable is positive.

The four variables, namely the background variable, input, process, and results, are positive so that the qualification is very successful. It proves that MEM implementation in those schools was conducted properly. Thus, the MEM implementation at those schools should be continued because an effective multicultural education will increase students positive attitude, especially tolerance, toward different sociocultural backgrounds [24,25].

\section{The Challenges in MEM Implementation and their Solutions}

The obstacles faced in implementing MEM programs are as follows. (1) The background variables include low community participation and the socio-economic status of the community. (2) In the input variable, the lack of stakeholder knowledge about the MEM program's mission and the existence of facilities and infrastructure for multicultural program management process, the process of cooperation, and participation. (4) In the outcome variable, the lack of public response and non-academic achievement. 
Efforts that can be made to overcome these obstacles are as follows:

1) In the background variable: It is necessary to extract community support through a program of requesting funds for people who have financial potential, special teaching programs for people who are concerned about the development and management of multicultural education, cooperation programs with the business world that contain business development programs and human resources oriented towards achieving success through a multicultural mindset. With the improvement of the community's social conditions, the interest in multicultural education will be lower. It is necessary to improve the people's perspective on the management of multicultural education.

2) In the input variable: To increase knowledge about each program's mission, it is necessary to socialize program participants and other school members about each program's mission. It is necessary to regulate program implementation so that existing equipment, materials, and study spaces can be used as effectively and efficiently as possible to improve facilities and infrastructure. School budget planning should be made to provide equipment and materials in stages, especially for equipment and materials that can be provided. Furthermore, it is necessary to provide tools, materials, and learning spaces in stages through obtaining financial support from parents, local governments, provincial governments, and the central government.

3) In the process variable: It is necessary to revitalize the organization at the institutional level and in each program by involving all education stakeholders such as school principals, teachers, employees, committees, students, parents, communities, cross-sectoral governments, and the business world, especially those related to MEM. Parents and social institutions (e.g., museums, cultural centers, etc.) have a potential role in supporting multicultural education [26]. Thus, it is necessary to directly assess the community, business world, and government to increase cooperation and participation. Furthermore, teachers' multicultural education competency should also be improved continuously through professional development [27].

4) In the outcome variable: It is necessary to continuously promote that the Indonesian people's mindset and cultural behavior patterns are non-negotiable in national and international interactions. Therefore, the management of multicultural education based on local potential needs to be continued [28].

This study is limited to the implementation of multicultural education at junior high schools. Since there are some problems were still found in the implementation of multicultural education, further research on the readiness of the student teachers to implement multicultural education in the Indonesian context is needed. All teachers include future teachers, need to be aware of students' socio-cultural differences, have a positive multicultural attitude, and be ready for multicultural education [29-33].

\section{CONCLUSION}

From the research results above, it can be concluded that the background of MEM is based on six foundations, namely philosophical, juridical, historical, sociological, geographic, and futuristic foundations [34]. For the schools that are the subject of research, all of them have challenges. Schools are expected to be able to compile and formulate a more proportional, cooperative, and competitive education unit level curriculum, carry out the teaching and learning process using a more innovative approach, improve the quality of education personnel through teacher deliberations [35], subjects, workshops, scientific research, adding to the qualifications of education personnel, and training. The MEM program's success on all variables, both the assessment of each indicator and each data source, is positive or high in supporting the MEM program at SMP/MTs in Bali Province. All of the research findings show the consistency of results from cause to effect from the program. However, as a program, it is still very far from perfect, and it was also found that several negative values from several indicators were a reflective meaning for the perfection of the program and efforts to achieve the targets that had been set [36]. Negative things and things that have not been achieved must be interpreted critically to find answers as alternative solutions to future problems.

\section{REFERENCES}

[1] I. B. Ardashkin, "Philosophy of Education as a Social Development Factor: World Trends and Prospects for Russia," Procedia - Soc. Behav. Sci., vol. 166, pp. 277-286, 2015, doi: 10.1016/j.sbspro.2014.12.524.

[2] M. Rowe and S. Dickel, Strategic Management; Methodological Approach. Canada: Addison Westlay Publishing Company, 1990.

[3] J. A. Banks, "Multicultural Education," in International Encyclopedia of the Social \& Behavioral Sciences, N. J. Smelser and P. B. Baltes, Eds. Oxford: Pergamon, 2001, pp. 10160-10163.

[4] R. P. Durán, "Cultural Issues that Can Affect the Validity of Educational Evaluations," in International Encyclopedia of Education (Third Edition), Third Edit., P. Peterson, E. Baker, and B. McGaw, Eds. Oxford: Elsevier, 2010, pp. 592-599.

[5] A. J. Love, "Understanding Approaches to Evaluation," in International Encyclopedia of Education (Third Edition), Third Edit., P. Peterson, E. Baker, and B. McGaw, Eds. Oxford: Elsevier, 2010, pp. 798-807.

[6] G. Lindsay, "Educational Evaluation: Overview," in International Encyclopedia of the Social \& Behavioral Sciences (Second Edition), Second Edi., J. D. Wright, Ed. Oxford: Elsevier, 2015, pp. 229-231.

[7] N. H. Moorcy, "Analisis Hubungan Kualitas Jasa dengan Kepuasan Nasabah \{BNI $\}$ Taplus pada Bank $\{B N I\}$ Cabang Utama Balikpapan," \{JSHP\} ( J. Sos. Hum. dan Pendidikan), vol. 1, no. 1, p. 34, Jul. 2017, doi: $10.32487 /$ jshp.v1i1.233.

[8] R. Picciotto, "Evaluation Governance and Planning," in International Encyclopedia of Education (Third Edition), Third Edit., P. Peterson, E. Baker, and B. McGaw, Eds. Oxford: Elsevier, 2010, pp. 607-613.

[9] Y. J. Ni, "Educational Evaluation: Concepts, Practice, and Future Directions," in International Encyclopedia of Education (Third Edition), Third Edit., P. Peterson, E. Baker, and B. McGaw, Eds. Oxford: Elsevier, 2010, pp. 518-529. 
[10] S. Demir and S. Özden, "The Evaluation of Multicultural Teaching Design Education Program,” Procedia - Soc. Behav. Sci., vol. 116, pp. 4732-4736, 2014, doi: https://doi.org/10.1016/j.sbspro.2014.01.1017.

[11] N. Demir and B. Yurdakul, "The Examination of the Required Multicultural Education Characteristics in Curriculum Design," Procedia - Soc. Behav. Sci., vol. 174, pp. 3651-3655, 2015, doi: https://doi.org/10.1016/j.sbspro.2015.01.1085.

[12] A. Maseleno, G. Hardaker, N. Sabani, and N. Suhaili, "Data on multicultural education and diagnostic information profiling: Culture, learning styles and creativity," Data Br., vol. 9, pp. 1048-1051, 2016, doi: https://doi.org/10.1016/j.dib.2016.11.024.

[13] A.-D. Popescu, S. Suciu, C. Borca, A. Nodea, and L. Ayotte, "Cultural Diversity Evaluation in Educational Learning Groups," Procedia Technol., vol. 19, pp. 1156-1163, 2015, doi: https://doi.org/10.1016/j.protcy.2015.02.165.

[14] J. Seo and J. Qi, "A multi-factor Paradigm for Multicultural Education in Japan: An Investigation of Living, Learning, School Activities and Community Life," Procedia - Soc. Behav. Sci., vol. 93, pp. 1498-1503, 2013, doi: https://doi.org/10.1016/j.sbspro.2013.10.071.

[15] K. Hakan and F. Seval, "CIPP evaluation model scale: Development, reliability and validity," Procedia - Soc. Behav. Sci., vol. 15, pp. 592599, 2011, doi: 10.1016/j.sbspro.2011.03.146.

[16] M. Lippe and P. Carter, "Using the CIPP Model to Assess Nursing Education Program Quality and Merit," Teach. Learn. Nurs., vol. 13, no. 1, pp. 9-13, 2018, doi: https://doi.org/10.1016/j.teln.2017.09.008.

[17] W. Warju, "Educational Program Evaluation using CIPP Model," Innov. Vocat. Technol. Educ., vol. 12, no. 1, pp. 36-42, 2016, doi: 10.17509/invotec.v12i1.4502.

[18] M. AbdiShahshahani, S. Ehsanpour, N. Yamani, S. Kohan, and B. Hamidfar, "The Evaluation of Reproductive Health PhD Program in Iran: A CIPP Model Approach,” Procedia - Soc. Behav. Sci., vol. 197, no. February, pp. 88-97, 2015, doi: 10.1016/j.sbspro.2015.07.059.

[19] J. W. Creswell, Research Design: Qualitative, Quantitative, Mix Methods Approaches, 3rd ed. London: SAGE Publication, 2009.

[20] D. L. Stufflebeam, "The CIPP Model for Evaluation," in International handbook of educational evaluation, 9th ed., T. Kellaghan, D. L. Stufflebeam, and L. A. Wingate, Eds. Dordrecht: Kluwer Academic Publishers, 2003, pp. 31-62.

[21] N. Omar, M. A. C. Noh, M. I. Hamzah, and L. A. Majid, "Multicultural Education Practice in Malaysia," Procedia - Soc. Behav. Sci., vol. 174 pp. 1941-1948, 2015, doi: https://doi.org/10.1016/j.sbspro.2015.01.859.

[22] J. Kyun, K. Chung, S. Ryu, and A. Han, "Multicultural Education in Korean Early Childhood Classroom: Based on the Educational Community Perspective," Procedia - Soc. Behav. Sci., vol. 174, pp. 2036-2039, 2015, doi: https://doi.org/10.1016/j.sbspro.2015.01.873.

[23] N. Szelei, L. Tinoca, and A. S. Pinho, "Rethinking 'cultural activities': An examination of how teachers utilised student voice as a pedagogical tool in multicultural schools," Teach. Teach. Educ., vol. 79, pp. 176187, 2019, doi: https://doi.org/10.1016/j.tate.2018.12.020.

[24] D. Martin, "Good education for all? Student race and identity development in the multicultural classroom," Int. J. Intercult. Relations, vol. $39, \quad$ pp. 110-123, 2014, doi: https://doi.org/10.1016/j.ijintrel.2013.10.005.

[25] N. Ratmaningsih, A. Abdulkarim, D. S. Logayah, and R. Fitria, "Multicultural Education: Between Freedom and Tolerance," Adv. Soc. Sci. Educ. Humanit. Res., vol. 251, no. January, pp. 717-718, 2018, doi: 10.2991/acec-18.2018.160.

[26] O. K. Logvinova, "Socio-pedagogical Approach to Multicultural Education at Preschool," Procedia - Soc. Behav. Sci., vol. 233, pp. 206210, 2016, doi: https://doi.org/10.1016/j.sbspro.2016.10.203.

[27] N. Szelei, L. Tinoca, and A. S. Pinho, "Professional development for cultural diversity: the challenges of teacher learning in context," Prof. Dev. Educ., vol. 46, no. 5, pp. 780-796, 2020, doi: 10.1080/19415257.2019.1642233

[28] B. R. E. al Worthern, Program Evaluation Alternative Approaches and Practical Guidlines. New York: Longman, 1987

[29] T. N. R. T. M. Maasum, N. Maarof, and M. M. Ali, “Addressing Student Diversity via Culturally Responsive Pedagogy," Procedia - Soc. Behav. Sci., vol. 134, pp. 101-108, 2014, doi: https://doi.org/10.1016/j.sbspro.2014.04.227

[30] K. Téllez, "What student teachers learn about multicultural education from their cooperating teachers," Teach. Teach. Educ., vol. 24, no. 1, pp. 43-58, 2008, doi: https://doi.org/10.1016/j.tate.2006.07.014.

[31] J. Pentikäinen, "The Use of Literature in Developing Multicultural Sensitivity in Teacher Training," Procedia - Soc. Behav. Sci., vol. 45, pp. 189-196, 2012, doi: https://doi.org/10.1016/j.sbspro.2012.06.555.

[32] I. Paul-Binyamin and K. Haj-Yehia, "Multicultural education in teacher education: Shared experience and awareness of power relations as a prerequisite for conflictual identities dialogue in Israel," Teach. Teach. Educ., vol. 85, pp. 249-259, 2019, doi: https://doi.org/10.1016/j.tate.2019.06.021.

[33] C. S. Abacioglu, M. Volman, and A. H. Fischer, "Teachers' multicultural attitudes and perspective taking abilities as factors in culturally responsive teaching,” Br. J. Educ. Psychol., vol. 90, no. 3, pp. 736-752, 2020, doi: 10.1111/bjep.12328.

[34] R. Reingold, "Promoting a True Pluralistic Dialogue: A Particularistic Multicultural Teacher Accreditation Program," Int. J. Multicult. Educ., vol. 9, no. 1, pp. 1-14, 2007, doi: http://dx.doi.org/10.18251/ijme.v9i1.6.

[35] W. González-espada, "Multicultural Education: Helping All Students Succeed In Science,” Electron. J. Lit. Through Sci., vol. 3, no. 12, 2004.

[36] W. C. Parker, teaching Democracy: Unity And Diversity In Public Life. New York: Teachers College Press. 